\title{
Remediation of Lead Contaminated Paddy Field Using Ramie Plants Combined with Bioremediation Agents and Inorganic Fertilizer
}

\author{
Sutami $^{1}$, R Rosariastuti ${ }^{2 *}$, Purwanto ${ }^{2}$ \\ ${ }^{1}$ Master Student Soil Science Program, Graduate School, Universitas Sebelas Maret, Surakarta 57126, \\ Indonesia \\ ${ }^{I}$ Department of Soil Science, Faculty of Agriculture, Universitas Sebelas Maret, Surakarta 57126, Indonesia \\ *Corresponding author Email: retnobs@staff.uns.ac.id
}

\begin{abstract}
Industrial waste containing heavy metals used for wetland irrigation will affect the heavy metals content in the soil. The accumulation of heavy metals in the soil may result in reducing microbial activity, soil fertility, soil quality, and heavy metals compounds in agricultural products. Agricultural products contaminated by heavy metals can influence human health. The purpose of this study was to reduce the $\mathrm{Pb}$ content in $\mathrm{Pb}$ contaminated paddy fields. This research was conducted in a contaminated paddy field using factorial research and a Completely Randomized Block Design consisting of 3 factors : P (Inorganic fertilizer), B (Bioremediation agents), $\mathrm{T}$ (Ramie). Every treatment combination was repeated 3 times. This study used a combination of Ramie with Rhizobium sp. I3 or manure as bioremediation agents to improve Pb uptake by plants so could decrease soil $\mathrm{Pb}$. The results showed that the bioremediation agents were able to increase $\mathrm{Pb}$ uptake by Ramie. Rhizobium $\mathrm{sp}$. I3 gave the highest $\mathrm{Pb}$ uptake of $103.77 \mathrm{mg} . \mathrm{kg}-1$ or 2 more times than control. The best treatment in decreasing $\mathrm{Pb}$ is with inorganic fertilizer, Rhizobium sp. I3 and Ramie (P1B1T1) with Pb soil $8.57 \mathrm{mg} . \mathrm{kg}-1$ or $8.4 \%$ than control and with inorganic fertilizer.
\end{abstract}

Key words: Lead, phytoremediation, Rhizobium sp. I3, Ramie

\section{INTRODUCTION}

Environmental pollution by heavy metals, especially lead $(\mathrm{Pb})$, is one of the most serious environmental problems [1]. $\mathrm{Pb}$ is very toxic to living organisms including animals, plants and microorganisms. The existence of excessive $\mathrm{Pb}$ in the soil will cause soil degradation and threaten the ecosystem of life on the land [2]. Accumulation of heavy metals in soil can reduce microbial activity, soil fertility, and heavy metal compounds in agricultural products that result in human health problems [3]. Phytoremediation is an environmentally friendly technology that utilizes plants in decontaminating heavy metals from the environment. Phytoremediation is a green technology used to remove pollutants from the environment [4][5]. Plant Growth Promoting Rhizobacteria (PGPR) will colonize planting roots and other beneficial plants to provide growth promoting substances [6]. The use of Plant Growth Promoting Rhizobacteria (PGPR) can influence the plant growth through their ability to produce fitohormon, siderophore, Indole Acetic Acid (IAA) hormone, nutrients, ACC-deaminase [7]. One of plants that can be utilized for phytoremediation with high economics is Ramie. Ramie (Boehmeria nivea L.) was used as phytoremediation agent because it has hyper accumulator qualities Ramie also has a high economic value because the fiber can be used as raw material for woven crafts and it is known that the quality of fiber does not decrease when the heavy metal content increases in its plant tissue [8]. Fertilization, pesticides and other agricultural activities are important activities to increase agricultural production [9]. The study by Rosariastuti [10] based on bioassay on Ramie isolate I3 and combination of treatment of isolate 
I3 + compost in grumusol and regosol, effectively increased dry weight and 2-fold uptake of chromium roots and shoots (phytostabilization and phytoextraction). Based on the existing research, it is expected that Ramie can reduce the content of $\mathrm{Pb}$ in paddy soil so that inoculated by Rhizobium sp. I3 bacteria or manure on Ramie in accumulating heavy metal $\mathrm{Pb}$ needs to be known and studied further. The purpose of this study was to determine the effect of inorganic fertilizers and bioremediation agents (Rhizobium sp. I3 and manure) on $\mathrm{Pb}$ absorption in $\mathrm{Pb}$ contaminated soil by Ramie and to find out which treatment gives the highest $\mathrm{Pb}$ absorption by Ramie and the most reduced soil $\mathrm{Pb}$ content.

\section{MATERIALS AND METHODS}

\subsection{Study Area}

This research was conducted from May to November 2017 in Waru Village, Kebakkramat District, Karanganyar Regency, Central Java, Indonesia with the coordinates of Latitude 7³0'36,036 S', and Longitude 11054'23,548' E. The Analysis of soil samples and plant samples were carried out in the Laboratory of Soil Biology and Biotechnology, Soil Physics and Conservation, Laboratory of Chemistry and Soil Fertility, Universitas Sebelas Maret. Heavy metal analysis measurements were carried out at the Integrated Laboratory at the Agricultural Environment Research Center in Pati Regency, Central Java.

\subsection{Materials and Equipment}

The material used included Rhizobium sp I3 isolated by Rosariastuti [10], cow manure, inorganic fertilizers in the form of urea, $\mathrm{KCl}$, and SP-36 obtained from farm shops, Ramie plant seedlings from Wonosobo, Central Java, and media Luria Bertani broth which has composition: $10 \mathrm{~g}$ peptone composition from Himedia Laboratories, $5 \mathrm{~g}$ yeast extract from Unipath ISD, $5 \mathrm{~g} \mathrm{NaCl}$ and $15 \mathrm{~g}$ agar [11]. Chemicals needed for wet destruction were destilled water, $\mathrm{NaCl}$, Alcohol, $\mathrm{HNO}_{3}{ }^{-}$and $\mathrm{HClO}_{4}^{-}$. The equipment needed were sample ring, test tube, flacon, pipette, erlenmeyer, $\mathrm{pH}$ meter, electric oven, refrigerator, Balance Sheet Analytic, hot plate and stirrer, Autoclave, vortex, shaker, fume hood, AAS (Atomic Absorption Spectrophotometer) and hoe.

\subsection{Research Design}

This research uses factorial research design with the basic design of Completely Randomized Block Design (CRBD). There are 3 factors used, namely inorganic fertilizer (P0: no inorganic fertilizer, P1: inorganic fertilizer), bioremediation agents (B0: without bioremediation agents ; B1: Rhizobium sp.
I3: B2: manure), and Ramie plant (T0; without Ramie; T1; Ramie). These three factors combined to produce 12 combinations of treatment that then repeated 3 times.

\subsection{Procedure}

\subsubsection{Preparation of Rhizobium sp.I3}

1 slant medium contains the isolate of Rhizobium sp. I3 was inoculated to $100 \mathrm{ml}$ Luria Bertani. Starter was shaken for 3 days and then poured into the medium Luria Bertani broth with more volume of $900 \mathrm{ml}$ as a scale up. The media is shaked until bacterial cell density reaches $10^{8}$ cells $/ \mathrm{ml}$.

\subsubsection{Preparation of Ramie and Fertilizer}

Ramie is from Wonosobo, Central Java. Ramie seedlings are propagated by the stem cutting method. Inorganic fertilizers and manure used in purchasing from agricultural production facilities providers. Provision of fertilizer for Ramie is $10.000 \mathrm{~kg} / \mathrm{ha}$ of manure. In addition to organic fertilizers, inorganic fertilizers are given at the beginning of planting with a dose of $60 \mathrm{~kg} \mathrm{~N}+20$ $\mathrm{kg}_{2} \mathrm{O}_{5}+30 \mathrm{~kg} \mathrm{~K}_{2} \mathrm{O} /$ ha.

\subsubsection{Land preparation and planting}

Land preparation consists of clearing land from weeds and making of plot treatment. Plot of treatment was made as much as 36 pieces. Each plot consists of $25 \mathrm{sub}$ plots of treatment. Each treatment combination was applied on a paddy field plot having the size of $2.5 \mathrm{~m} \times 2.5 \mathrm{~m}$. Distance of plant size is $50 \mathrm{~cm} \times 50 \mathrm{~cm}$. One plot contained 25 sub-plots. Each sub-plot was planted with two Ramie seedlings. Upkeep was done by regulating water irrigation, and weeding the grass. Five samples were randomly selected in each plot

\subsubsection{Laboratory Analysis}

Observed parameters were soil characteristics including soil $\mathrm{pH}$ (potentiometric method), Cation Capacity Exchange (CEC) (ammonium treatment method), Soil Organic Matter (Walkley-Black method), Population of bacteria Rhizobium sp. I3 (Plate Count method) and the level of $\mathrm{Pb}$ (wet destruction method followed by reading with AAS) [15].

\subsubsection{Data Analysis}

Data were analyzed using ANOVA F 5\% test continued by Duncan Multiple Range Test (DMRT) and then for knowing relationships among variables were analyzed using correlation analysis. 


\section{RESULTS AND DISCUSSIONS}

\subsection{Effect of Treatment to Soil Variables}

Table 1. Soil characteristics

\begin{tabular}{|c|c|c|c|c|c|}
\hline Treatment & $\mathrm{pH}$ & $\begin{array}{l}\mathrm{OM} \\
(\%)\end{array}$ & $\begin{array}{l}\text { CEC } \\
\left(\mathrm{cmol}^{\mathrm{kg}} \mathrm{kg}^{-1}\right)\end{array}$ & 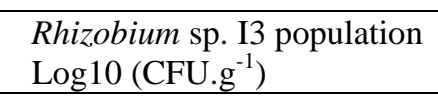 & Content $\mathrm{Pb}\left(\mathrm{mg} \cdot \mathrm{kg}_{-}{ }^{1}\right)$ \\
\hline & & & & & 9.36de \\
\hline Р0В0Т0 & $6.79 c$ & 4.73 & 37.01 & $13.2 \mathrm{cde}$ & \\
\hline P0B0T1 & $6.69 c$ & 4.69 & 45.01 & 13.13defg & $9.26 \mathrm{de}$ \\
\hline Р0B1T0 & $6.45 a$ & 4.81 & 32.54 & $13.15 \mathrm{def}$ & $9.75 b c$ \\
\hline P0B1T1 & $6.85 c$ & 4.44 & 36.98 & $13.38 \mathrm{ab}$ & $9.45 \mathrm{de}$ \\
\hline Р0В2Т0 & $6.73 b c$ & 4.93 & 36.85 & 13.13defg & $10.31 \mathrm{a}$ \\
\hline P0B2T1 & $6.82 c$ & 4.82 & 49.82 & 13.29abcd & $10.56 \mathrm{a}$ \\
\hline Р1B0T0 & $6.6 \mathrm{ab}$ & 4.75 & 45.23 & $12.99 \mathrm{fg}$ & $9.54 \mathrm{~cd}$ \\
\hline P1B0T1 & $6.76 c$ & 4.64 & 55.28 & $13.34 \mathrm{abc}$ & $9.95 b$ \\
\hline P1B1T0 & $6.75 b c$ & 5.02 & 47.69 & $13.28 \mathrm{bcde}$ & $9.16 \mathrm{e}$ \\
\hline P1B1T1 & $6.79 c$ & 4.69 & 39.86 & $13.44 \mathrm{a}$ & $8.57 \mathrm{f}$ \\
\hline Р1B2T0 & $6.84 c$ & 5.21 & 42.11 & $13.07 \mathrm{efg}$ & $9.37 \mathrm{de}$ \\
\hline P1B2T1 & $6.82 c$ & 4.81 & 45.52 & $12.96 \mathrm{~g}$ & $9.44 \mathrm{de}$ \\
\hline
\end{tabular}

Note: the same small letters or no letters written in the same column showing no significant difference

\subsubsection{Soil pH}

According to the ANOVA results, manure and interaction of inorganic fertilizer, bioremediation agents and Ramie increased soil $\mathrm{pH}$. The highest dose of $\mathrm{N}$ fertilizer gave the lowest $\mathrm{pH}$ [12]. Table 1 show that the highest increase of $\mathrm{pH}$ was in the treatment of without inorganic fertilizer+Rhizobium sp I3+Ramie (P0B1T1) of 6.85. A pH value that is close to neutral can support biological activity in the soil and the process of degradation and binding of heavy metals [13]. Soil pH is influenced by both acid and base-forming ions in the soil. Common acid-forming cations (positively charged dissolved ions) are hydrogen $\left(\mathrm{H}^{+}\right)$, aluminum $\left(\mathrm{Al}^{3+}\right)$, and iron $\left(\mathrm{Fe}^{2+}\right.$ or $\left.\mathrm{Fe}^{3+}\right)$, whereas common base-forming cations include calcium $\left(\mathrm{Ca}^{2+}\right)$, magnesium $\left(\mathrm{Mg}^{2+}\right)$, potassium $\left(\mathrm{K}^{+}\right)$and sodium $\left(\mathrm{Na}^{+}\right)$[14]. Based on the correlation test, soil $\mathrm{pH}$ was positively and closely correlated ( $\mathrm{p}>0.05)$ to Rhizobium sp. I3 population $(\mathrm{r}=0.259)$. Acidic soil reaction $(\mathrm{pH})$ affects the development of soil microorganisms that live in it. Fungi can live and tolerate soil $\mathrm{pH}$ ranges from $\mathrm{pH} 4-6.5$ while for bacteria prefer soil conditions with a $\mathrm{pH}$ ranging from 6-7 [15].

\subsubsection{Soil Organic Matter}

According to the ANOVA results, Rhizobium sp. I3 and manure increased soil organic matter. Table 1 show that, the highest increase was in P1B2T0 treatment of $5.21 \%$. In order to increase the SOM content and improve soil fertility, organic fertilization is the most efficient approach [16]. Based on the correlation test, soil organic matter was positively correlated with soil CEC $(r=0.294)$ and negatively correlated with Rhizobium sp. I3 population $(\mathrm{r}=0.228)$ but the correlation was not close. Organic fertilizers play crucial role for SOM accumulation, aggregate formation and influence microbial community composition and cooccurrence networks in microhabitats [16] .

\subsubsection{Soil CEC}

According to the ANOVA results, manure increased soil CEC. The increase in CEC was caused by the addition of manure which will increase the organic matter content of the soil. The addition of manure into the soil will increase the CEC so that it can increase the absorption of heavy metals in the soil. Based the result of Fitamo et al. of the same soils revealed that considerable proportions of the total levels of heavy metals were extracted from the non-residual fractions, and CEC and $\mathrm{pH}$ were key factors in the distribution of heavy metals among these fractions [17]. The increase of CEC will increase the exchangeable metal. Based on soil correlation test, CEC is positively and closely correlated ( $\mathrm{p}<0.05)$ with soil organic matter $(r=0.294)$ and soil $\mathrm{pH}(\mathrm{r}=0.177)$. Increase CEC soil along with the increase of soil organic matter. The soil CEC is also negatively correlated ( $p>0.05$ ) with the population of Rhizobium sp I3 $(\mathrm{r}=0.625)$. The correlation 
between soil CEC and population of Rhizobium sp. I3 was very close. Bacteria produce metabolite products such as enzymes, organic acids, EPS etc, which can increase CEC and metal exchangeability.

\subsubsection{Rhizobium sp. I3 Population}

According to the ANOVA results, Rhizobium sp. I3, Ramie and their interaction increased Rhizobium sp. I3 population. The highest Rhizobium sp. I3 population was in treatment P1B1T1, which was 13.44 Log10 (CFU.g ${ }^{-1}$ ) (Table 1). The Rhizobium sp. I3 significantly increased the total population of Rhizobium sp. I3, indicating that Rhizobium sp. I3 was able to adapt to polluted soils of $\mathrm{Pb}$ heavy metals, to survive in metal contamination, bacteria develop several types of mechanisms to tolerate heavy metal ion removal. The metal ion transfer mechanism out of the cell accumulates and forms metal ion compounds into the cell, thereby converting toxic metals into non-toxic ones. Based on the correlation test, the population of Rhizobium sp. I3 was positively correlated with soil $\mathrm{pH}(\mathrm{r}=$ 0.259 ). The higher the population of Rhizobium $\mathrm{sp}$. I3, pH would increase. Total population of Rhizobium sp. I3 is negatively and not closely correlated with soil organic matter $(r=0.228)$, CEC $(\mathrm{r}=0.625)$, and $\mathrm{Pb}$ content in soil $(\mathrm{r}=0.137)$.

\subsubsection{Soil Pb content}

According to the ANOVA results, All treatments and their interaction decreased $\mathrm{Pb}$ level in soil. Soil $\mathrm{Pb}$ decreasing each treatment. P1B1T1 was able to lower $\mathrm{Pb}$ with the highest decrease of $8.57 \mathrm{mg} . \mathrm{kg}$ ${ }^{1}$ or $8.47 \%$ than control (Table 1). Ramie combined with other treatments has a higher effectiveness than without plants. A decrease of $\mathrm{Pb}$ metal in the soil can be caused by $\mathrm{Pb}$ metal up taking by plants through the roots. The plant's roots can excrete root exudates as nutrients for microorganisms such as bacteria. The bacteria itself can produce extracellular enzymes that can decompose organic matter [18]. Rhizobium sp. I3 can also reduce $\mathrm{Pb}$ levels in the soil because Rhizobium can increase $\mathrm{Pb}$ absorption by plants. This is in accordance with the statement of Rosariastuti [10] that Rhizobium can increase the absorption of heavy metals and translocations from roots to the shoot.

\subsection{Effect of Treatment to Plant Variables}

\subsubsection{Biomass of Ramie}

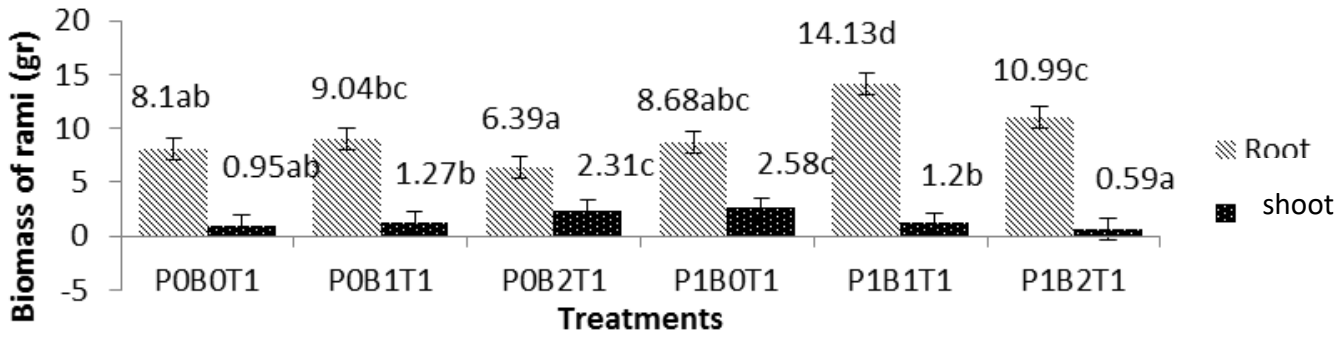

Figure 1. Biomass of Ramie

According to the ANOVA results, inorganic fertilizers and Rhizobium sp. I3 significantly influenced Ramie biomass. The inorganic fertilizers are able to provide the nutrients to the plant so as to increase the growth and productivity of the plant. Inorganic fertilizers, Rhizobium sp. I3 and manure are able to increase the root biomass of Ramie (Fig. 1). Root biomass is higher than that shoot biomass due to the morphological trait of the Ramie roots in the form of woody stems so as to increase the Ramie biomass. Rhizobium sp I3 and manure were able to increase the dry biomass of
Ramie. Rhizobacteria can produce IAA, Siderophores and ACC deaminase that can stimulate the growth of plants and protect plants from heavy metals toxicity [19]. Pteris vittata sporophytes inoculated with PG-12 were grown in $\mathrm{Pb}$-contaminated medium and exhibited improved growth, increased $\mathrm{P}$ uptake, and reduced $\mathrm{Pb}$ uptake into plant tissue compared to the control. Results demonstrated that viable PG-12 cells were responsible for $\mathrm{Pb}$ immobilization and plant growth enhancement in Pteris vittata [20]. 


\subsubsection{Pb Content and Uptake of Ramie}

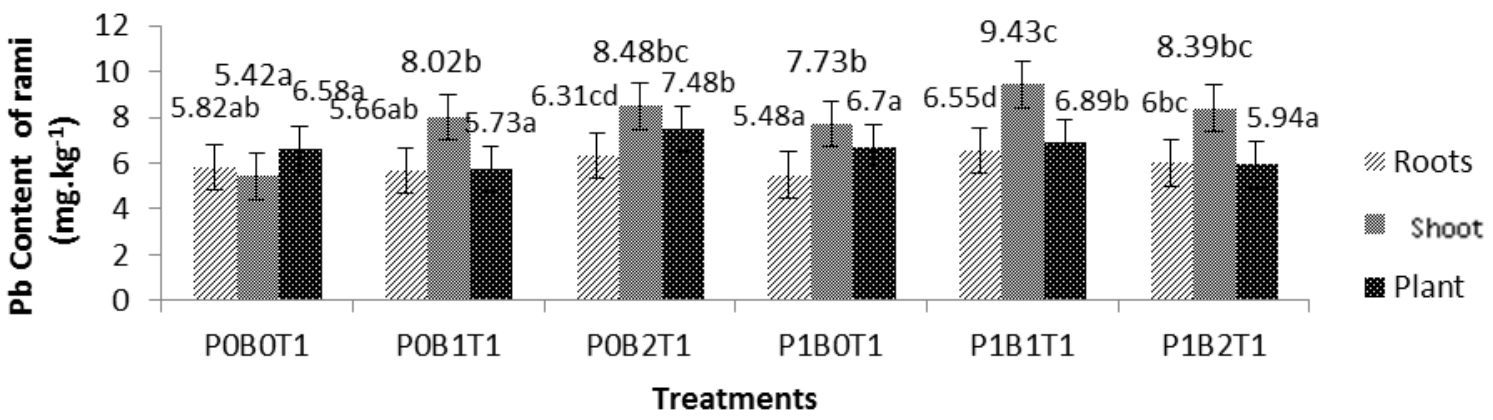

Figure. $2 \mathrm{~Pb}$ content of Ramie

According to the ANOVA results, applications of inorganic fertilizers, Rhizobium sp. I3 and manure, had significant influence on the level of $\mathrm{Pb}$ roots and Ramie shoot (Figure 2). Treatment using inorganic fertilizer+Rhizobium sp. I3+Ramie (P1B1T1) gave the highest increase $\mathrm{Pb}$ content reached to $9.43 \mathrm{mg} \cdot \mathrm{kg}^{-1}$ or $73.98 \%$ than control. Applications of inorganic fertilizers, Rhizobium sp $\mathrm{I} 3$ and manure, increased the level of $\mathrm{Pb}$ roots and Ramie shoot (Figure 2). Treatment using Rhizobium sp. I3 and inorganic fertilizer gave the highest increase $\mathrm{Pb}$ content reached to $9.43 \mathrm{mg} \cdot \mathrm{kg}^{-}$ ${ }^{1}$ or $73.98 \%$ than control. The resulting increase in trace metal uptake by the plants caused by microbial siderophores might enhance the effectiveness of phytoextraction processes of contaminated soil. The following section highlights the basic biology and chemistry of siderophores produced by bacteria [21]. Application of rhizosphere bacteria can increase the availability of heavy metals of $\mathrm{Pb}$ in the rhizosphere and increase plant growth [22]. Higher levels of $\mathrm{Pb}$ in shoot compared with plant roots showed that after planting for two months, Ramie was able to translocate $\mathrm{Pb}$ from the root to the shoot. Based on the correlation test, $\mathrm{Pb}$ level on Ramie positively correlated $(\mathrm{p}<0.05)$ to $\mathrm{Pb}$ uptake by Ramie $(\mathrm{r}=$ $0.482)$ and Ramie height $(r=0.543)$. Correlation between $\mathrm{Pb}$ content and Ramie height was close.

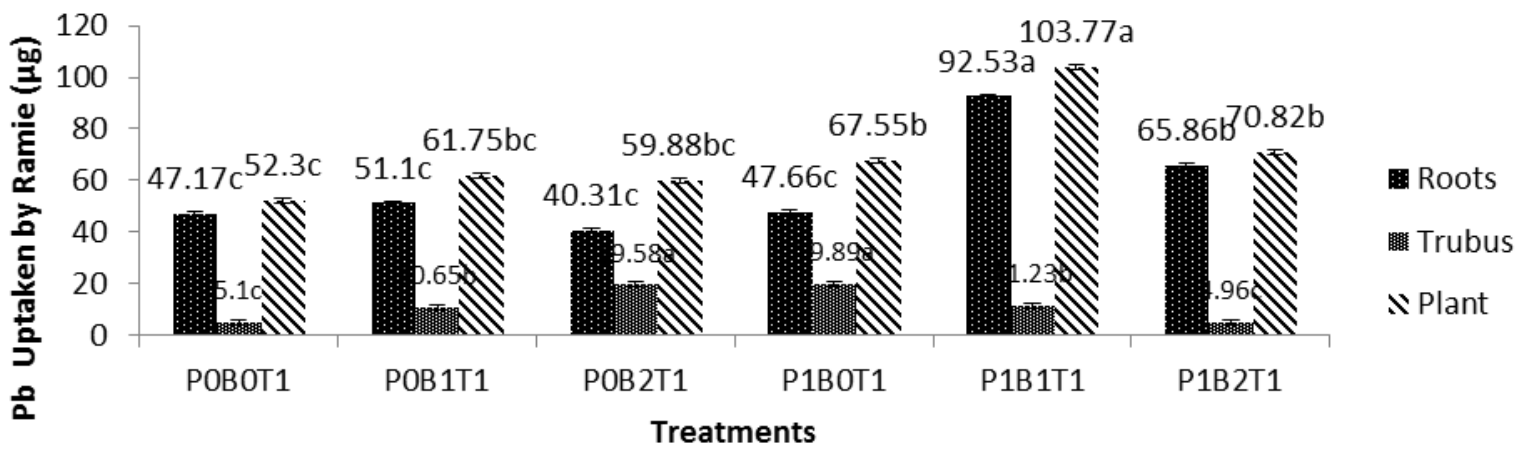

Figure 3. Pb uptake by Ramie

According to the ANOVA results, inorganic fertilizer and Rhizobium sp. I3 had significant influence on the uptake of $\mathrm{Pb}$ roots and Ramie shoot (Figure 3). The increase in plant biomass and metal concentration means an increase in $\mathrm{Pb}$ uptake by Ramie. Inorganic fertilizers and Rhizobium sp. I3 increased $\mathrm{Pb}$ uptake in the roots and shoots of Ramie. Increased plant biomass and metal concentrations mean increased $\mathrm{Pb}$ uptake by
Ramie. Rhizobium sp. I3, manure and inorganic fertilizers can increase the uptake of $\mathrm{Pb}$ in Ramie. All treatments can increase $\mathrm{Pb}$ uptake of Ramie. The highest increase was in the P1B1T1 treatment of $103.77 \mathrm{mg} \cdot \mathrm{kg}^{-1}$ or 2 more times than control. Rhizobium sp. can produce organic acids, such as oxalic acid and citrate. These organic acids have the ability to form complexes with metal cations in forms that are available and easily soluble in water 
to be absorbed by plants [23]. Based on the correlation test, $\mathrm{Pb}$ absorption by Ramie was positively correlated with $\mathrm{Pb}$ levels in Ramie $(\mathrm{r}=$ $0.482), \mathrm{Pb}$ uptake by roots $(\mathrm{r}=0.942)$, root dry weight $(r=0.913)$, total dry weight $(r=0.967)$ and plant height $(r=0.543)$, the correlation were very close. It means that the increase of plant biomass would increase $\mathrm{Pb}$ uptake.

\section{CONCLUSION}

Application of inorganic fertilizer, Rhizobium sp I3 or manure and Ramie increases soil $\mathrm{pH}$, and Rhizobium sp. population I3. The application of inorganic fertilizer, Rhizobium sp I3 or manure and Ramie also reduced the $\mathrm{Pb}$ content of the soil. The interaction between inorganic fertilizers+ Rhizobium sp I3+Ramie decreased soil $\mathrm{pH}$, soil $\mathrm{Pb}$ content. The use of a combination of inorganic fertilizers+ Rhizobium sp I3+Ramie was able to reduce $\mathrm{Pb}$ content in the soil with the highest decrease of $8.57 \mathrm{mg} . \mathrm{kg}-1$ or $8.47 \%$ lower than the control. The highest $\mathrm{Pb}$ uptake in the combination of inorganic fertilizer+Rhizobium sp. I3+Ramie were $103.77 \mathrm{mg} . \mathrm{kg}-1$ or 2 times higher than the control. The best treatments was P1B1T1. By this research, $\mathrm{Pb}$ contaminated soil can be handled and safe for planting crops.

\section{REFERENCES}

[1] Assi M.A., Hezmee M.N.M., Haron A.W., Sabri M.Y.M., and Rajion M.A., 2016. "The detrimental effects of lead on human and animal health," Vet. World, 9(6) 660-671, doi: 10.14202/vetworld.2016.660-671.

[2] Ranbir C.S, Naveen K. A., Richa K., 2019. Environmental Biotechnology: For Sustainable Future. Spinger

[3] Hukum. S, 2017. "Phytoremediation: A Green Technology to Clean Up the Sites with Low and Moderate Level of Heavy Metals," Austin Biochem, 2(2), 1012

[4] Laghlimi M, Baghdad B., El Hadi H., and Bouabdli A., 2015 "Phytoremediation Mechanisms of Heavy Metal Contaminated Soils: A Review," Open J. Ecol., 05(08), 375388, doi: 10.4236/oje.2015.58031.

[5] Ahmadpour P., Ahmadpour F., Mahmud T.M.M., Arifin Abdu, Solaimani, Tayafah F.H. 2012, "Phytoremediation of heavy metals: A green technology," African J. Biotechnol., 11(76), 14036-14043, doi: 10.5897/ajb12.459.

[6] Hassan M.K, John A.M. and Kloepper J.W, "The Interactions of Rhizodeposits with Plant Growth-Promoting Rhizobacteria in the
Rhizosphere:A Review," Agriculture, 9, 142; doi:10.3390/agriculture9070142.

[7] Rahma H., Nurbailis, and Kristina N., 2019. "Characterization and potential of plant growth-promoting rhizobacteria on rice seedling growth and the effect on Xanthomonas oryzae pv. Oryzae," Biodiversitas, 20 (12), 3654-3661, doi: 10.13057/biodiv/d201226.

[8] Wang X., Liu YO, Zeng GM, Chai LY, Song XC. 2008 "Subcellular distribution and chemical forms of cadmium in Boechmeria nivea (L.) Gaud.," Environ. Exp. Bot., 62 (3), 389-395,doi: 10.1016/j.envexpbot.2007.10.014.

[9] Kılıç O., Boz I, and Eryılmaz G.A., 2020 "Comparison of conventional and good agricultural practices farms: A socio-economic and technical perspective," J. Clean. Prod., 258, doi: 10.1016/j.jclepro.2020.120666.

[10] Rosariastuti R, Prijambada I.D., Ngadiman, Prawidyarini G.S., and Putri A.R, 2013 "Isolation and Identification of Plant Growth Promoting and Chromium Uptake Enhancing Bacteria from Soil Contaminated by Leather Tanning Industrial Waste," J. Basic Appl. Sci., 9, 243-251, doi: 10.6000/19275129.2013.09.32.

[11] Rajkumar M, Nagendran R., Lee K. J., Lee W. H., and Kim S. Z., 2006 "Influence of plant growth promoting bacteria and $\mathrm{Cr}^{6+}$ on the growth of Indian mustard," Chemosphere, 62 (5), pp. 741-748, doi: 10.1016/j.chemosphere.2005.04.117.

[12] Desta H. A., 2015 "Effects of Organic and Inorganic Fertilizers on Selected Soil Properties after Harvesting Maize at Antra Catchment, Northwestern Ethiopia," Int. Invent. J. Agric. Soil Sci., 3(5), 68-78

[13] Jankiewicz B. and Adamczyk D., 2008. "The influence of thiuram on the mobility of heavy metals in soils," Arch. Environ. Prot., 34(3), 83-90

[14] McCauley A., Jones C., and Jacobsen J., 2009 "Soil pH and Organic Matter," Nutr. Manag. Modul. 8, 1-12,[Online]. Available: https://citeseerx.ist.psu.edu/viewdoc/download ?doi=10.1.1.566.6336\&rep=rep1\&type=pdf.

[15] Zebua A. C., Guchi H., and Sembiring M. 2020, "Isolation of non-symbiotic Nitrogenfixing bacteria on andisol land affected by Sinabung eruption," IOP Conf. Ser. Earth Environ. Sci., 454(1), doi: 10.1088/17551315/454/1/012167.

[16] Lin Y., Ye G., Kuzyakov Y., Liu D., Fan J., and Ding W., 2019 "Long-term manure application increases soil organic matter and aggregation, and alters microbial community structure and keystone taxa," Soil Biol. Biochem., 134, 187-196, doi: 
10.1016/j.soilbio.2019.03.030.

[17] Fitamo D., Leta S., Belay G., Lemma B., and Olsson M., 2011 "Phytoavailability of Heavy Metals and Metalloids in Soils Irrigated with Wastewater, Akaki, Ethiopia: A Greenhouse Study," Soil Sediment Contam., 20(7), 745766, doi: 10.1080/15320383.2011.609196.

[18] Sinsabaugh R. L., Hill B. H., and Follsta J. J. Shah, 2009 "Ecoenzymatic stoichiometry of microbial organic nutrient acquisition in soil and sediment," Nature, 462(7274), 795-798, doi: 10.1038 /nature 08632 .

[19] Ahemad M. and Kibret M., 2014 "Mechanisms and applications of plant growth promoting rhizobacteria: Current perspective," J. King Saud Univ. - Sci., 26(1),. 1-20, doi: 10.1016/j.jksus.2013.05.001.

[20] Manzoor M.., 2019 "Metal tolerance of arsenic-resistant bacteria and their ability to promote plant growth of Pteris vittata in $\mathrm{Pb}-$ contaminated soil," Sci. Total Environ., 660, 18-24, doi: 10.1016/j.scitotenv.2019.01.013.

[21] Rajkumar M., Ae N., Prasad M. N. V., and Freitas H., 2010 "Potential of siderophoreproducing bacteria for improving heavy metal phytoextraction," Trends Biotechnol., 28(3), 142-149, doi: 10.1016/j.tibtech.2009.12.002.

[22] Sheng X. F., Xia J. J.,. Jiang C. Y, He L. Y., and Qian M., 2008 "Characterization of heavy metal-resistant endophytic bacteria from rape (Brassica napus) roots and their potential in promoting the growth and lead accumulation of rape," Environ. Pollut., 156 (3), 1164-1170, doi: 10.1016/j.envpol.2008.04.007.

[23] S. Mari, 2006 "Root-to-shoot long-distance circulation of nicotianamine and nicotianamine-nickel chelates in the metal hyperaccumulator Thlaspi caerulescens," J. Exp. Bot., 57(15) 4111-4122, doi: $10.1093 / \mathrm{j} x \mathrm{~b} / \mathrm{erl} 184$. 